Review

\title{
Design for sustainability models: A multiperspective review
}

\author{
Cristina Sousa Rocha ${ }^{a,}{ }^{*}$, Paula Antunes ${ }^{b}$, Paulo Partidário ${ }^{c}$ \\ ${ }^{\text {a }}$ LNEG - National Laboratory of Energy and Geology, Portugal \\ ${ }^{\mathrm{b}}$ CENSE - Center for Environmental and Sustainability Research, NOVA School of Science and Technology, NOVA University Lisbon, Portugal \\ ${ }^{\mathrm{c}}$ DGEG - Directorate General of Energy and Geology, Portugal
}

\section{A R T I C L E I N F O}

\section{Article history:}

Received 18 December 2018

Received in revised form

20 May 2019

Accepted 7 June 2019

Available online 12 June 2019

Handling Editor: Cecilia Maria Villas Bôas de Almeida

\section{Keywords:}

Design for sustainability

Design management

DfS models

Corporate sustainability management

Social responsibility

\begin{abstract}
A B S T R A C T
Several authors have identified limitations in the uptake of design for sustainability (DfS) in companies and value chains. In spite of the extensive literature on the subject, researchers and practitioners still do not share a common overview on the subject, which hinders operationalization efforts. This paper proposes that DfS adoption is more likely to be successful if informed by corporate sustainability management and design management theories. Therefore, an analytical framework has been developed and applied to systematically analyse ten published design for sustainability models, which were identified through an extensive literature review. The analytical framework is composed of nine building blocks, or elements, organized in three levels: strategic, tactical and operational. To facilitate a more detailed and objective analysis of the selected models against each element, 22 questions have been established. The findings show that while some authors have focused on abstract models that support companies in establishing a vision and concepts for (more) sustainable products and services, others offer more instrumental approaches to guide the different phases of design. On the level of the building blocks, there is a considerable alignment of the models with the analytical framework; the detailed mechanisms and processes for implementation, however, vary a lot. Overall, difficulties related to developing a sustainability vision that guides the design for sustainability process, co-creating with stakeholders and harmonizing environmental, social and economic criteria were identified. The social dimension of design for sustainability is still poorly established and tackled in a multi-level, non-systemized way. The paper concludes with promising research directions focusing on design for sustainability.
\end{abstract}

() 2019 Published by Elsevier Ltd.

\section{Contents}

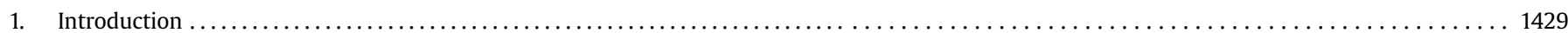

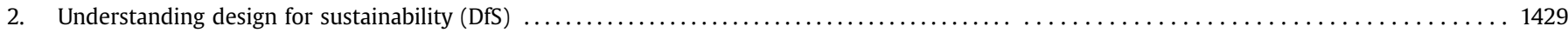

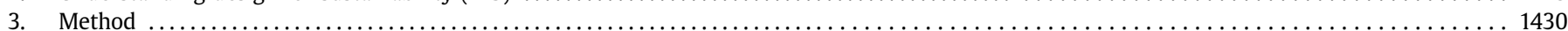

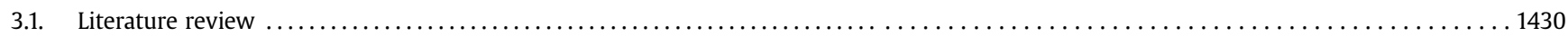

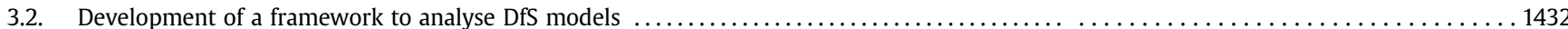

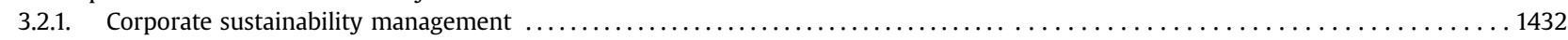

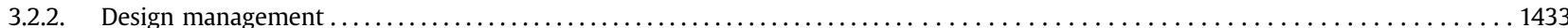

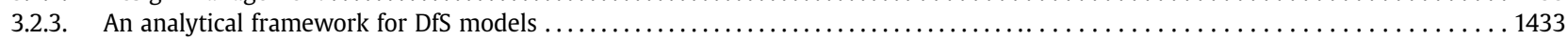

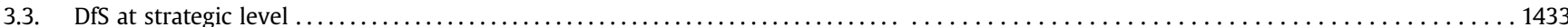

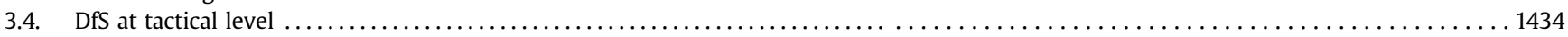

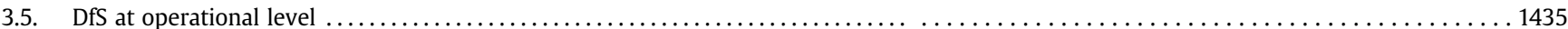

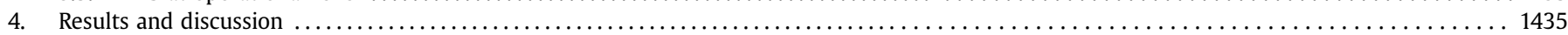

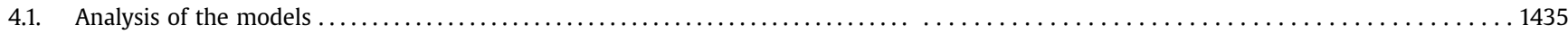

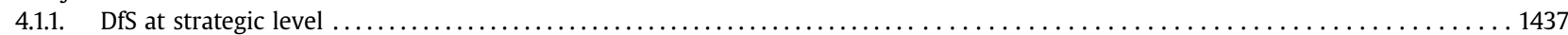

\footnotetext{
* Corresponding author. LNEG, Estrada do Paço do Lumiar, 22 - Ed. C, 1699-038,
} LISBOA, Portugal.

E-mail address: Cristina.Rocha@Ineg.pt (C.S. Rocha). 